\title{
Common and Rare Genetic Risk Factors for Glaucoma
}

\author{
Ryan Wang and Janey L. Wiggs \\ Department of Ophthalmology, Harvard Medical School, Massachusetts Eye and Ear Infirmary, \\ Boston, Massachusetts 02114 \\ Correspondence: janey_wiggs@meei.harvard.edu
}

The characterization of genes responsible for glaucoma is the critical first step toward the development of gene-based diagnostic and screening tests, which could identify individuals at risk for disease before irreversible optic nerve damage occurs. Early-onset forms of glaucoma affecting children and young adults are typically inherited as Mendelian autosomal dominant or recessive traits whereas glaucoma affecting older adults has complex inheritance. In this report, we present a comprehensive overview of the genes and genomic regions contributing to inherited glaucoma.

\section{RATIONALE FOR DISCOVERY OF GENES CONTRIBUTING TO GLAUCOMA}

The he characterization of genes responsible for glaucoma is the critical first step toward the development of gene-based diagnostic and screening tests, which could identify individuals at risk for disease before irreversible optic nerve damage occurs. Current glaucoma therapies are limited to reducing elevated intraocular pressure (IOP), a major risk factor for the disease. The discovery of disease-related genes could provide new insights into the underlying molecular mechanisms responsible for glaucoma that could form the basis of novel gene-based therapies, including strategies for neuroprotection. Understanding the role of the protein product in health and disease will also provide new insights into the underlying molecular mechanisms responsible for disease.
Glaucoma can affect individuals of all ages. Early-onset forms of glaucoma affecting children and young adults are typically inherited as Mendelian autosomal dominant or recessive traits whereas glaucoma affecting older adults has complex inheritance. Early-onset forms of glaucoma are rare whereas adult-onset forms are more common.

\section{RARE VARIANTS CAUSING EARLY-ONSET GLAUCOMA WITH AUTOSOMAL DOMINANT OR AUTOSOMAL RECESSIVE INHERITANCE}

Compared with adult-onset glaucoma, earlyonset forms of glaucoma are rare with incidence ranging from $1 / 2500$ to $1 / 20,000$, depending on the condition and the population (Stoilov et al. 1997; Beijani et al. 2000; Chakrabarti et al. 2010). Genetic variants causing early-onset

Editors: Eric A. Pierce, Richard H. Masland, and Joan W. Miller

Additional Perspectives on Retinal Disorders: Genetic Approaches to Diagnosis and Treatment available at

www.perspectivesinmedicine.org

Copyright (C) 2014 Cold Spring Harbor Laboratory Press; all rights reserved; doi: 101101/cshperspect.a017244

Cite this article as Cold Spring Harb Perspect Med 2014;4:a017244 
R. Wang and J.L. Wiggs

glaucoma are highly penetrant, although variable expressivity may be observed. The genes currently known to cause early-onset glaucoma are listed in Table 1. All of these genes were initially identified using genetic linkage analyses of large, multigenerational families. These genes are responsible for congenital glaucoma (CYP1B1 and LTBP2), developmental glaucoma (PITX2, FOXC1, PAX6, and LMX1B), juvenileonset primary open angle glaucoma (MYOC), and familial normal-tension glaucoma (OPTN and $T B K 1)$.

\section{Congenital Glaucoma}

Congenital glaucoma (or infantile glaucoma) typically develops before three years of age (Aponte et al. 2010). The condition is primarily inherited as an autosomal recessive trait, although autosomal dominant families have been described (Sarfarazi et al. 2000). Genetic linkage studies have identified three loci likely to contain genes contributing to congenital glaucoma: GLC3A (2p21), GLC3B (1p36), and GLC3C (14q22) (Safarazi et al. 1995; Akarsu et al. 1996; Stoilov and Sarfarazi 2002). Two genes have been discovered: CYP1B1, encoding cytochrome P450 1B1 (GLC3A), and LTBP2 (latent transforming growth factor binding protein 2) (Ali et al. 2009; Beijani et al. 2000). Mutations in both CYP1B1 and LTBP2 cause autosomal recessive disease.

CYP1B1 mutations are the most common cause of congenital glaucoma worldwide (Stoi- lov et al. 1997). Disease-causing mutations include missense mutations, nonsense mutations, frameshifts, and large-gene deletions (Stoilov et al. 1997; Sarfarazi 2000; Michels-Rautenstrauss et al. 2001). Although these mutations are highly penetrant, variable expressivity is a well-known feature of CYP1B1-related disease. Genotype-phenotype studies have suggested that mutations causing premature truncation of the protein (frameshifts, deletions, insertions, and nonsense mutations) cause more severe disease with earlier onset than disease caused by missense mutations. The gene product, cytochrome P450 1B1, metabolizes complex molecules such as polycyclic aromatic hydrocarbons and 17 $\beta$-estradiol (Tokizane et al. 2005; Tsuchiya et al. 2005; Sowers et al. 2006). The role of the protein in congenital glaucoma is not clear; however, it has been hypothesized that cytochrome P450 1B1 activity is responsible for metabolism of compounds involved in ocular development (Choudhary et al. 2008; Choudhary et al. 2009).

LTBP2 (Latent transforming growth factor, TGF, $\beta$-binding protein 2 ) was initially identified as the causative gene in patients with earlyonset glaucoma from Pakistan and in patients of Gypsy ethnicity (Ali et al. 2009; Narooie-Nejad et al. 2009). The gene is located 1.3 Mb from the GLC3C locus on 14q22; however, LTBP2 mutations have not been identified in the family initially used to define the GLC3C locus, suggesting that a second congenital glaucoma gene is located in this region (Sharafieh et al. 2013).

Table 1. Genes responsible for early-onset glaucoma

\begin{tabular}{|c|c|c|c|c|}
\hline Disease & $\begin{array}{l}\text { Juvenile open- } \\
\text { angle glaucoma }\end{array}$ & $\begin{array}{c}\text { Anterior segment } \\
\text { dysgenesis }\end{array}$ & Congenital glaucoma & $\begin{array}{l}\text { Familial normal- } \\
\text { tension glaucoma }\end{array}$ \\
\hline Genes & MYOC & PITX2, FOXC1, PAX6 & CY1B1, LTBP2 & OPTN, TBK1 \\
\hline $\begin{array}{l}\text { Protein } \\
\text { function }\end{array}$ & $\begin{array}{l}\text { Extracellular } \\
\text { matrix }\end{array}$ & $\begin{array}{l}\text { Developmental } \\
\text { regulation of gene } \\
\text { expression }\end{array}$ & $\begin{array}{l}\text { Cytochrome P450 1B1 } \\
\text { (CYP1B1); extracellular } \\
\text { matrix }(L T B P 2)\end{array}$ & $\begin{array}{l}\text { TNF- } \alpha \text { signaling, } \\
\text { autophagy }\end{array}$ \\
\hline Mutation & $\begin{array}{l}\text { Endoplasmic } \\
\text { reticulum stress }\end{array}$ & $\begin{array}{c}\text { Abnormal ocular } \\
\text { development }\end{array}$ & $\begin{array}{c}\text { Abnormal ocular } \\
\text { development }\end{array}$ & $\begin{array}{l}\text { Increased rate retinal } \\
\text { ganglion cell } \\
\text { apoptosis }\end{array}$ \\
\hline Reference(s) & Stone et al. 1997 & $\begin{array}{l}\text { Gould et al. 1997; } \\
\text { Mears et al. 1998; } \\
\text { Riise et al. } 2001\end{array}$ & $\begin{array}{l}\text { Stoilov et al. 1997; } \\
\text { Ali et al. } 2009\end{array}$ & $\begin{array}{l}\text { Rezaie et al. 2002; } \\
\text { Morton et al. } 2008\end{array}$ \\
\hline
\end{tabular}


The LTBP2 protein is located in the extracellular matrix, where it associates with micofibrils containing fibrillin-1 (Jelodari-Mamaghani et al. 2013). Interestingly, LTBP2 mutations have been associated with Weill-Marchesani and Weill-Marchesani-like syndrome, a condition characterized by microspherophakia and abnormal ocular anterior segment development (Haji-Seyed-Javadi et al. 2012). LTBP2 appears to be a rare cause of congenital glaucoma in ethnically diverse populations, such as in the United States (Lim et al. 2012).

\section{Developmental Glaucoma}

Abnormal development of the anterior segment can lead to dysgenesis of critical anterior segment structures involved in glaucoma, including the trabecular outflow pathways and Schlemn's canal. Developmental glaucoma may be syndromic (Axenfeld-Rieger syndrome and aniridia) or limited to only ocular involvement. Some patients with anterior segment dysgenesis never develop glaucoma, whereas others have very severe disease evident at birth (Gould and John 2002). Four genes coding for proteins involved in regulation of gene expression can contribute to developmental glaucoma (PITX2, FOXC1, PAX6, and $L M X 1 B$ ). Mutations in these genes cause autosomal dominant disease with high penetrance but variable expressivity both within and among affected families. The phenotypic features of disease caused by these genes, as well as those caused by CYP1B1 and LTBP2, are similar, making it impossible to establish the genetic diagnosis through clinical examination alone (Fig. 1). Genetic testing can establish a molecular diagnosis as well as clarify the inheritance information necessary for accurate genetic counseling.

PITX2 and LMX1B cause syndromic forms of developmental glaucoma (Rieger syndrome and Nail-Patella syndrome, respectively). Approximately $50 \%$ of patients with PITX2 mutations develop glaucoma (Reis et al. 2012). Recently, mutations involving a genomic region distal to PITX2 have been identified as disease causing (Volkmann et al. 2011). Patients with $L M X 1 B$ mutations are affected by Nail-Patella

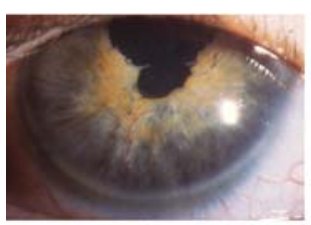

CYP1B1

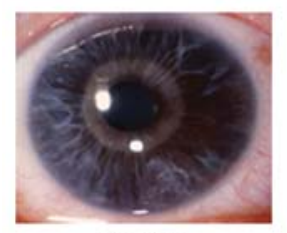

FOXC1

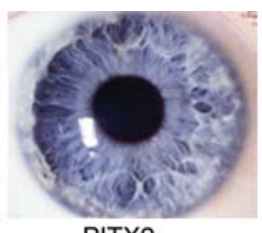

PITX2

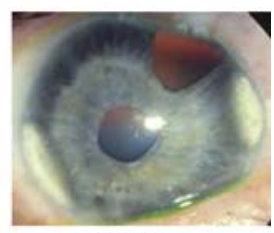

FOXC1
Figure 1. Anterior segment phenotypes in patients with developmental glaucoma. Anterior segment photographs taken with a camera attached to a slitlamp are shown for four patients with mutations in genes associated with early-onset glaucoma. Notable features are peripheral corneal opacification (CYP1B1), irido-corneal adhesions (PITX2) and iris atrophy (FOXC1). In the patients with FOXC1 mutations the atrophic iris makes it possible to see the pupillary sphincter muscle, which is normally not visible because of overlying iris stroma.

syndrome, which can involve the eye, causing a variety of glaucoma-related features (Chen et al. 1998; Dreyer et al. 1998; Mimiwati et al. 2006). Mutations in PAX6 cause abnormal development of stem cells in the iris and corneal limbus, resulting in a broad range of clinical features, from agenesis of the iris to corneal opacification caused by a deficiency of limbal stem cells (Hingorani et al. 2009). FOXC1 was initially identified as a gene responsible for iris hypoplasia (Mears et al. 1998). Subsequent studies have identified cardiac abnormalities and possibly other systemic features in patients with mutations in these genes (Gould et al. 1997; Swiderski et al. 1999; Winnier et al. 1999).

\section{Juvenile-Onset Primary Open-Angle Glaucoma}

Patients affected by open-angle glaucoma have disease despite normal anatomic structures.

Adult-onset primary open-angle glaucoma (POAG) develops after 50 years of age, whereas juvenile-onset (or early-onset) open-angle glau- 
coma affects children and young adults, with onset typically between the ages of 3 and 20. Juvenile open-angle glaucoma is inherited as an autosomal dominant trait (Wiggs et al. 1998) and is characterized by very high IOP (Wiggs et al. 1995; Johnson et al. 1996). Linkage studies using large families have identified a number of juvenile open-angle glaucoma loci: GLC1A (1q24.3-q25.2) (Sheffield et al. 1993), GLC1J (9q22) (Wiggs et al. 2004), GLC1K (20p12) (Wiggs et al. 2004), GLC1M (5q22.1q32) (Wang et al. 2004; Pang et al. 2006; Fan et al. 2007), and GLC1N (15q22-q24) (Wang et al. 2006). Among these loci only one gene, MYOC, coding for myocilin, has been identified (Kubota et al. 1997; Stone et al. 1997). Missense changes in the protein account for $10 \%$ of the cases of juvenile open-angle glaucoma and also $3 \%-5 \%$ of the cases of adult-onset POAG (Wiggs et al. 1998; Fingert et al. 1999). Diseasecausing mutations are primarily located in the protein's olfactomedin domain (Fig. 2) (Adam et al. 1997; Stone et al. 1997; Fingert et al. 1999). Myocilin is an extracellular protein of unknown function, and loss of the protein function does not result in glaucoma (Wiggs and Vollrath 2001; Kim et al. 2001), suggesting that the underlying genetic mechanism is likely to be a gain-of-function or dominant-negative effect. Additionally, a common nonsense variant located in exon 1 (Fig. 2) is a benign polymorphism and does not cause glaucoma or any other phenotype (Lam et al. 2000). Disease-causing mutations reduce the solubility of the protein, leading to protein misfolding and subsequent protein aggregation in the endoplasmic reticulum (Aroca-Aguilar et al. 2010). The misfolded protein response may lead to a loss of trabecular meshwork cells, resulting in high IOP (Joe et al. 2003). Interestingly, limiting protein aggregation using the small molecule phenyl butyrate (PBA) causes reduction in IOP both in vitro and in vivo, possibly pointing to novel gene-based therapy for patients with myocilin mutations (Yam et al. 2007; Zode et al. 2011, 2012). Recently, common variants in genes coding for multiplexin collagens XV and XVIII have been shown to modify the severity of myocilin-related glau-

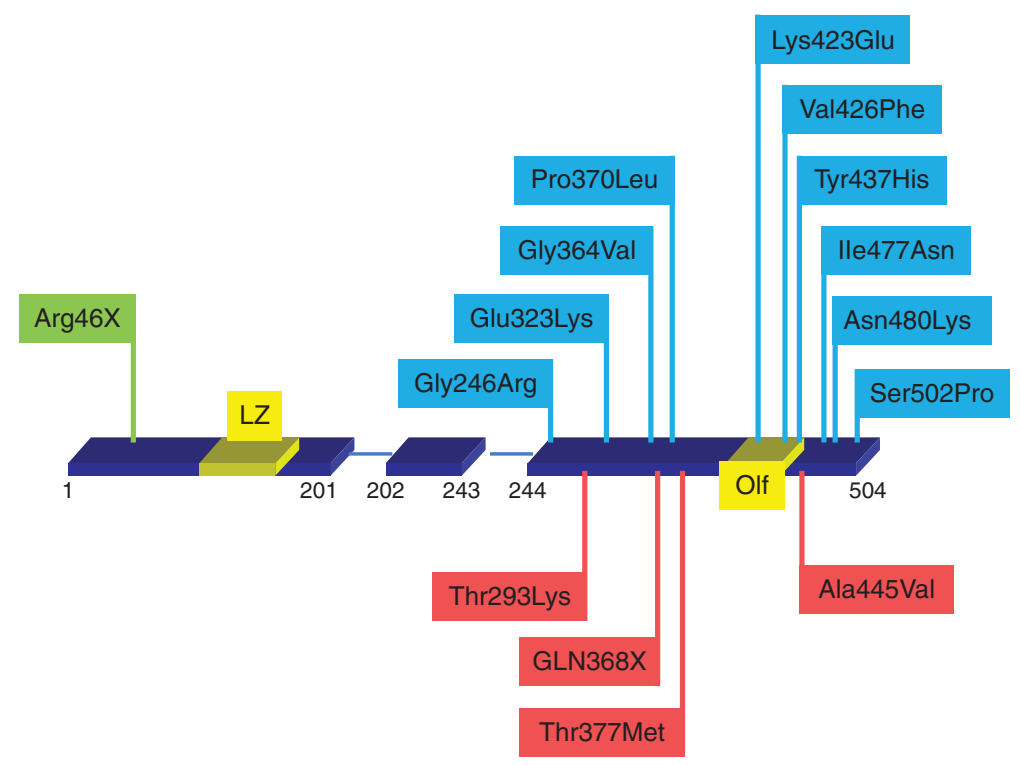

Figure 2. MYOC mutations causing glaucoma. The gene location of selected MYOC mutations known to cause glaucoma are shown. Exon 1 extends from codon 1-201, exon 2 from codon 202-243, and exon 3 from codon 244-504. Exon 1 contains a leucine zipper (LZ) and exon 3 contains the Olfactomedin domain (Olf). Mutations causing early-onset glaucoma are shown in blue, adult-onset glaucoma in red, and a nonsense mutation known to be a benign polymorphism in green. 
coma, suggesting that myocilin may interact with these protein in the extracellular matrix and/or in maintaining the integrity of the trabecular outflow pathways (Liton et al. 2005; Wiggs et al. 2013b).

\section{Familial Normal-Tension Glaucoma}

Normal-tension glaucoma (NTG) is a type of open-angle glaucoma characterized by optic nerve degeneration despite normal IOP. Most NTG patients have adult-onset disease; however, rarely, the disease can have early onset with autosomal dominant inheritance. Two genes have been associated with familial NTG: OPTN and TBK1 (Rezaie et al. 2002; Morton et al. 2008; Fingert et al. 2011).

Rare missense mutations in OPTN, which encodes optineurin and particularly the E50K mutation, cause a severe early-onset familial form of NTG. (Aung et al. 2005; Morton et al. 2008). Optineurin is involved in basic cellular functions including protein trafficking, maintenance of the Golgi apparatus, as well as the NF-кB pathway, antiviral responses, and antibacterial signaling (Ying 2012). Of interest, optineurin interacts with Tank1 (TBK1), which has also been implicated in familial NTG (Morton et al. 2008). The optineurin E50K mutation causes the protein to become inactive and/or insoluble (Minegeshi et al. 2013). This mutation also enhances the interaction of optineurin with Tank1 (Fingert et al. 2011).

\section{COMMON VARIANTS CONTRIBUTING TO ADULT-ONSET GLAUCOMA WITH COMPLEX INHERITANCE}

POAG, adult-onset NTG, pseudoexfoliation glaucoma, and primary angle-closure glaucoma are common traits with complex inheritance. Genetic variants contributing to these conditions have been identified using genome-wide association approaches (Thorleifsson et al. 2007, 2010; Burdon et al. 2011; Vithana et al. 2012; Wiggs et al. 2012, 2013a). Generally, variants contributing to common complex traits such as adult-onset glaucoma have small individual effects on disease development. Aggregated effects from multiple risk factors, including environmental risk factors, can have a larger impact. Robust genetic associations have been observed for POAG (CDKN2BAS [Burdon et al. 2011; Wiggs et al. 2012], SIX1/SIX6 [Wiggs et al. 2012], CAV1/CAV2 [Thorliefsson et al. 2010; Wiggs et al. 2011], TMCO1 [Burdon et al. 2011]), NTG (CDKN2BAS [Wiggs et al. 2012] and a regulatory region on 8q22 [Wiggs et al. 2012]), pseudoexfoliation (LOXL1 [Thorleifsson et al. 2007]), and primary angle-closure glaucoma (PLEKHA7 and COL11A1 [Vithana et al. 2012]) (Table 2). Additionally, genetic variants associated with quantitative ocular traits that are risk factors for common forms of glaucoma have also been identified. These include IOP (van Koolwijk et al. 2012), central corneal thickness (CCT) (Vithana et al. 2011; Lu et al. 2013), and optic nerve parameters including

Table 2. Genes/loci contributing to adult-onset glaucoma

\begin{tabular}{|c|c|c|c|}
\hline Gene & Disease & Function & Reference(s) \\
\hline CDKN2BAS & POAG, NTG & Cell cycle regulation, TGF- $\beta$ signaling & $\begin{array}{l}\text { Burdon et al. 2011; } \\
\text { Wiggs et al. } 2012\end{array}$ \\
\hline TMCO1 & POAG & Unknown & Burdon et al. 2011 \\
\hline SIX1/SIX6 & POAG & Optic nerve development & $\begin{array}{l}\text { Fan et al. 2011; Ramdas } \\
\text { et al. } 2011\end{array}$ \\
\hline $\begin{array}{l}8 \mathrm{q} 22 \\
\text { enhancer }\end{array}$ & NTG & $\begin{array}{l}\text { Regulation of fluid production in } \\
\text { ciliary body and choroid plexus }\end{array}$ & Wiggs et al. 2012 \\
\hline$C A V 1 / C A V 2$ & POAG & Endothelial membranes & Thorleifsson et al. 2010 \\
\hline LOXL1 & Pseudoexfoliation & Elastinogenesis and maintenance & Thorleifsson et al. 2007 \\
\hline PLEKHA7 & Angle-closure glaucoma & Adherens junction protein & Vithana et al. 2012 \\
\hline COL11A1 & Angle-closure glaucoma & Sclera development & Vithana et al. 2012 \\
\hline
\end{tabular}


cup-to-disc ratio and optic nerve area (Ramdas et al. 2010; Macgregor et al. 2010; Axenovich et al. 2011) (Table 3).

The clinical features of POAG generally include both elevated IOP and optic nerve degeneration. Patients with optic nerve disease without elevation of IOP are referred to as the NTG subgroup. Large genome-wide association studies (GWAS) have been completed for POAG in the Icelandic population (Thorleifsson et al. 2010), Australian population (Burdon et al. 2011), and in the United States (Wiggs et al. 2012). The Icelandic study identified a significant association between genetic variants located in the CAV1/CAV2 genomic region and POAG. This finding has been replicated in a case-control sample from the US (Wiggs et al. 2011) and recently, CAV1/CAV2 variants have been shown to be preferentially associated with patients who have loss of the central visual field early in the disease (Loomis et al. 2014). Both the Australian and the US studies identified significant associations with CDKN2BAS, a long noncoding antisense RNA that inhibits the expression of CDKN2B, an inhibitor of CDK4, a protein involved in promoting cell division (Burdon et al. 2011; Wiggs et al. 2012). The Australian study showed significant association with variants in the TMCO1 genomic region, a gene that also appears to be associated with elevated IOP (see below). The US study identified significant association with variants in the SIX1/ SIX6 genomic region; these are also associated with the cup-to disc ratio, a quantitative optic nerve parameter (Ramdas et al. 2010; Wiggs et al. 2012).
NTG

Optic nerve degeneration without IOP elevation $(<21 \mathrm{mmHg})$ is the defining clinical feature of NTG. Identifying the genetic factors that contribute to this condition could provide important insights into neuroprotective therapies for glaucoma. An analysis of the NTG subgroup in a large genome-wide association study of POAG using a United States case-control sample identified common variants in the $C D K N 2 B A S$ region and a novel regulatory region on chromosome $8 \mathrm{q} 22$ as significant risk factors (Wiggs et al. 2012). The 8q22 region is a DNaseI hypersensitivity site that has high activity in the choroid plexus, which is responsible for the production of cerebrospinal fluid, and the ciliary body, which is responsible for the production of aqueous humor. Interestingly, recent hypotheses suggest that the translaminar pressure across the lamina cribrosa may be a risk factor for optic nerve damage, and this pressure gradient is defined by the difference between the IOP and cerebrospinal fluid pressure (Jonas and Wang 2013).

\section{Pseudoexfoliation Syndrome}

Pseudoexfoliation syndrome is a generalized disorder of extracellular matrix that results in a chronic deposition of fibrillar aggregates throughout the ocular anterior segment. Accumulation of the fibrillar material in the trabecular meshwork is thought to contribute to the development of glaucoma associated with this condition (Schlötzer-Schrehardt et al. 1995;

Table 3. Selected genes/loci contributing to quantitative ocular traits related to glaucoma

\begin{tabular}{llll}
\hline Gene & \multicolumn{1}{c}{ Trait } & \multicolumn{1}{c}{ Function } & \multicolumn{1}{c}{ Reference(s) } \\
\hline CDKN2BAS & Cup-to-disc-ratio & Cell cyle regulation, TGF- $\beta$ signaling & Fan et al. 2011; Ramdas et al. 2011 \\
SIX1/SIX6 & Cup-to-disc-ratio & Developmental protein & Fan et al. 2011 \\
ATOH7 & Optic nerve area & Developmental protein & Macgregor et al. 2010 \\
TMCO1 & IOP & Unknown function & van Koolwijk et al. 2012 \\
GAS7 & IOP & Unknown function & van Koolwijk et al. 2012 \\
ZNF469 & CCT & $\begin{array}{c}\text { Regulates expression of extracellular } \\
\text { matrix components }\end{array}$ & Abu et al. 2008 \\
COL5A1 & CCT & Extracellular matrix & Lu et al. 2013 \\
COL8A2 & CCT & Extracellular matrix & Vithana et al. 2011 \\
\hline
\end{tabular}


Naumann et al. 1998). A genome-wide association study conducted in the Icelandic population first identified common variants in the LOXL1 gene as significant risk factors (Thorleifsson et al. 2007). Subsequently, association between LOXL1 gene variants and pseudoexfoliation has been replicated in populations worldwide (Fan et al. 2011). LOXL1 (lysyl-oxidale like 1 ) is necessary for formation and maintenance of elastin. It is not yet known how LOXL1 variants influence development of pseudoexfoliation; however, recent evidence suggests that the variants associated with disease cause a decrease in gene expression, possibly resulting in reduced enzyme activity (Schlotzer-Schrehardt 2009). The LOXL1 risk alleles are very common in pseudoexfoliation cases $(95 \%-99 \%)$ but are also common in the normal population $(60 \%-80 \%)$ suggesting that the gene variants are necessary but not sufficient for disease development (Fan et al. 2011). Recently, residence in northern latitudes has been identified as an environmental risk factor for this condition (Stein et al. 2011; Kang et al. 2012).

\section{Primary Angle-Closure Glaucoma}

Primary angle-closure glaucoma is common in Asian countries. A recent genome-wide association study using five independent Asian case-control samples identified three genomic regions statistically associated with POAG: rs3753841 (COL11A1), rs1015213 (located between PCMTD1 and ST18), and rs11024102 (PLEKHA7) (Vithana et al. 2012). All of these single-nucleotide polymorphisms were also replicated in a combined Australian-Nepalese case-control sample (Awadalla et al. 2013). COL11A1 is expressed in the sclera, and mutations in COL11A1 are known to cause Stickler's syndrome, a condition that includes myopia, among other ocular features (Richards et al. 1996). As primary angle-closure glaucoma can be related to hyperopia, the genome-wide association study results may point to a role for COL111A1 in development of refractive errors, possibly because of abnormal scleral development.

\section{Quantitative Ocular Traits that Are Risk Factors for Glaucoma}

For traits with complex inheritance, it can be useful to identify genetic factors influencing the underlying individual traits, such as IOP, optic nerve parameters, and CCT, that contribute to the overall disease (Charlesworth et al. 2010). These traits are quantitative, highly heritable, and show substantial variation in human populations. IOP is the only modifiable risk factor for glaucoma. Recent genome-wide analyses using normal populations have identified two genes significantly associated with IOP, GAS7 and TMCO1 (van Koolwijk et al. 2012). Similar analyses for optic nerve parameters associated with glaucoma risk have identified CDKN2BAS and SIX1SIX6 as genetic risk factors contributing to cup-to-disc-ratio (Ramdas et al. 2010; Fan et al. 2011) and ATOH7 as an important determinant of optic nerve size (Macgregor et al. 2010). Populations from around the world have been used to identify genetic factors contributing to CCT, one of the most heritable of the quantitative ocular traits (Toh et al. 2005). A recent study from the International Glaucoma Genetics Consortium (IGGC) identified 16 loci significantly associated with CCT (Fig. 3) (Lu et al. 2013). Pathway analyses suggested that collagen and extracellular matrix pathways are important regulators of CCT ( $\mathrm{Lu}$ et al. 2013).

\section{COMPLEX INTERACTIONS: GENE- ENVIRONMENT, GENE-GENE INTERACTIONS, AND EPIGENETIC EFFECTS}

Complex genetic and gene-environment interactions are expected to contribute to the genetic architecture of common adult-onset disorders. Nutritional factors, such as dietary fat, antioxidant intake, and other lifestyle factors including smoking and postmenopausal hormone use may influence the development of POAG (Pasquale and Kang 2009). A gene-environment interaction involving hormone replacement therapy and NOS3 (the gene coding for nitric oxide synthase 3 ) has been identified as a risk 
R. Wang and J.L. Wiggs

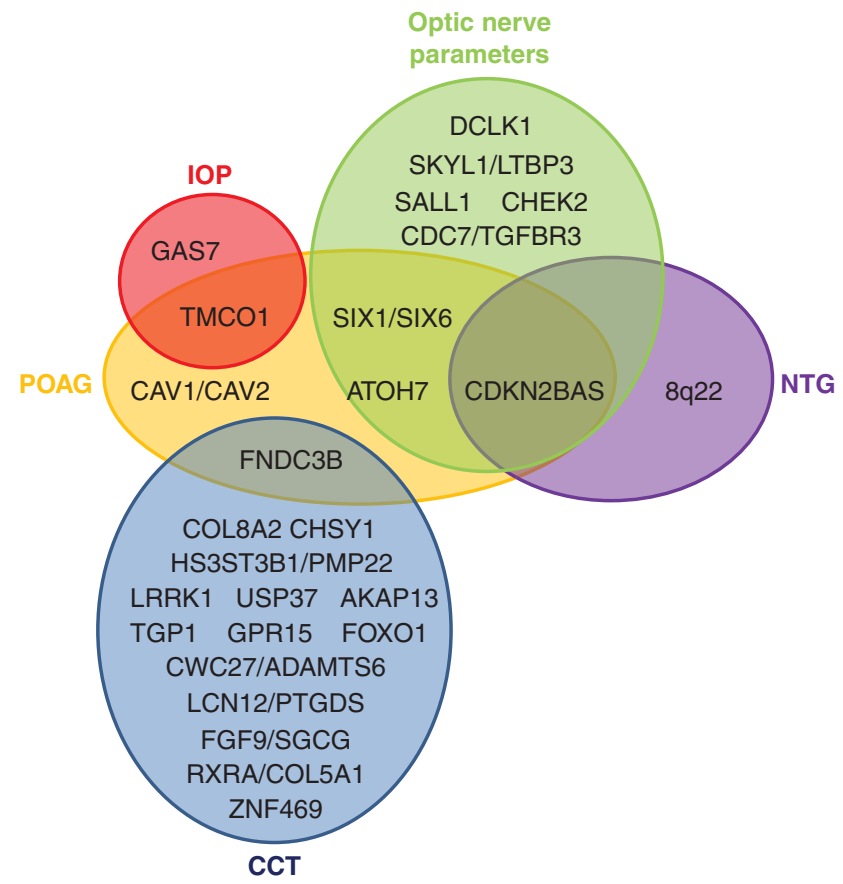

Figure 3. Gene and genomic regions with common variants that contribute to glaucoma and glaucoma-related ocular quantitative traits. Variants contributing to both primary open-angle glaucoma and normal tension glaucoma as well as selected ocular quantitative traits (CCT, IOP, and optic nerve parameters) are shown. Gene names are presented in dark font. Genes contributing to POAG are contained in the orange ellipse, NTG in the purple ellipse, CCT in the blue ellipse, IOP in the red ellipse, and optic nerve parameters in the green ellipse. Genes that contribute to more than one trait are indicated by their placement in the overlapping regions. For example, CDKN2BAS contributes to NTG, POAG, and to optic nerve parameters.

factor for POAG (Kang et al. 2010). The estrogen metabolism pathway is also associated with POAG in women (Pasquale et al. 2013). Genegene interactions contributing to POAG have been suggested for WDR36 and $p 53$ (both influencing apoptosis) (Blanco-Marchite et al. 2011) and for genetic variants in $A T O H 7$ and SIX1/ SIX6 (Fan et al. 2011).

\section{BIOLOGICAL PATHWAYS AND PROCESSES SUGGESTED BY GENETIC VARIANTS CONTRIBUTING TO GLAUCOMA}

Genome-wide association studies have identified multiple genes potentially involved in glaucoma pathogenesis; however, the stringent correction for multiple testing and type I error identifies only variants with the largest main effects as statistically significant (Manolio et al.
2008). Many biologically meaningful associations of smaller effect size may go undetected; including variants with smaller effect size in systematic groups could reveal novel biological pathways or systems underlying disease susceptibility. Pathway-based analysis groups gene variants into biologically meaningful entities to distinguish the actual from the false-positive associations. In short, this type of analysis can be used to uncover additional genotype-phenotype associations that the single-allele genomewide association analysis may have missed. Hypothesis-independent pathway analyses suggest that the underlying molecular pathogenesis of POAG involves a broad range of biological processes, including cell adhesion, immune responsiveness, energy metabolism, and neurotransmission (Cooke Bailey et al. 2013). Identification of genes contributing to both early-on- 
set and adult-onset forms of glaucoma are also highlighting biological pathways and processes of importance to glaucoma pathogenesis. Several of these are discussed below.

\section{Extracellular Matrix Metabolism}

Maintenance of extracellular matrix is emerging as an important theme in glaucoma pathogenesis (Acott et al. 2008; Crawford Downs et al. 2011). Several of the genes contributing to early-onset glaucoma (MYOC, LTBP2, COL18A1) and adult-onset glaucoma (LOXL1) have important roles in extracellular matrix (Ueda et al. 2002; Ali et al. 2009; Sethi et al. 2011; Wiggs et al. 2013b), and three important genes related to CCT impact extracellular matrix ( $\mathrm{Lu}$ et al. 2013). Further investigation of genes shown to contribute to extracellular processes in ocular tissues relevant to glaucoma could be of interest.

\section{Transforming Growth Factor $\beta$ (TGF- $\beta$ ) Signaling}

TGF- $\beta$ I and TGF- $\beta$ II appear to have important roles in optic nerve degeneration (Zode et al. 2009; Fuchshofer 2011) as well as trabecular meshwork function (Sethi et al. 2011; Fuchshofer 2012). LTPB2 (associated with congenital glaucoma and anterior segment dysgenesis) and CDKN2BAS (associated with POAG, NTG) are part of the overall TGF- $\beta$ signaling pathway. Additionally, NTG pathway analysis showed significant association with the TGF- $\beta$ signaling pathway overall (Wiggs et al. 2012).

\section{Tumor Necrosis Factor $\alpha$ (TNF- $\alpha)$ Signaling}

Both genes contributing to familial NTG (OPTN, TBK1) can impact TNF- $\alpha$ signaling (Fingert et al. 2011). Blocking of the TNF- $\alpha$ receptor in an animal model of glaucoma appears to be neuroprotective (Roh et al. 2012). These results suggest that TNF- $\alpha$ signaling can have an important role in ganglion cell apoptosis in glaucoma. Higher levels of soluble TNF- $\alpha$ have been identified in women before the development of NTG (Kang et al. 2013), a finding consistent with this hypothesis.

\section{Estrogen Metabolism}

The hormone $17 \beta$-estradiol can regulate expression of both CAV1 and NOS3 (both associated with POAG), and loss of caveolin-1 function can cause increased expression of NOS3 (Zhou et al. 2009; Sud et al. 2010), suggesting an interaction between these proteins. Additionally, P450 1B1 (CYP1B1, associated with congenital glaucoma) is an important factor in estrogen metabolism (Hanna et al. 2000). Gender effects in glaucoma have also been suggested by studies showing that estrogen receptors are expressed on the retinal ganglion cells of the optic nerve (Munaut et al. 2001), and that estrogen may have a neuroprotective effect in animal models of glaucoma (Zhou et al. 2007; Russo et al. 2008). Further studies examining gender effects in POAG, and gender interactions with genes contributing to this disorder will be of interest.

\section{CONCLUDING REMARKS}

Genes responsible for both early-onset and adult-onset glaucoma have been identified using genetic and genomic technologies and approaches. Family-based genetic linkage analyses have yielded disease-causing genes for earlyonset glaucoma, whereas genome-wide association studies have identified genes and genomic regions contributing to adult-onset forms of the disease. Biological pathways contributing to glaucoma and other complex interactions (gene-gene and gene-environment) are emerging. Future directions for new gene discovery include whole exome sequencing and other next generation sequencing technologies, genome-wide association studies using larger numbers of cases and controls and including rare variant analyses, and further evaluation of the contributions of biological pathways, genegene and gene-environment interactions.

\section{REFERENCES}

Abu A, Frydman M, Marek D, Pras E, Nir U, Reznik-Wolf H, Pras E. 2008. Deleterious mutations in the Zinc-Finger 469 gene cause brittle cornea syndrome. Am J Hum Genet 82: $1217-1222$. 
Acott TS, Kelley MJ. 2008. Extracellular matrix in the trabecular meshwork. Exp Eye Res 86: 543-561.

Adam MF, Belmouden A, Binisti P, Brézin AP, Valtot F, Béchetoille A, Dascotte JC, Copin B, Gomez L, Chaventré A, et al. 1997. Recurrent mutations in a single exon encoding the evolutionarily conserved olfactomedin-homology domain of TIGR in familial open-angle glaucoma. Hum Mol Genet 6.12: 2091-2097.

Akarsu A, Nurten M, Erol Turacli S, Gulderen Aktan, Magda Barsoum-Homsy, Line Chevrette, B, Sitki Sayli, Mansoor Sarfarazi. 1996. A second locus (GLC3B) for primary congenital glaucoma (Buphthalmos) maps to the $1 \mathrm{p} 36$ region. Hum Mol Genet 5: 1199-1203.

Ali M, McKibbin M, Booth A, Parry DA, Jain P, Riazuddin SA, Hejtmancik JF, Khan SN, Firasat S, Shires M, et al. 2009. Null mutations in $L T B P 2$ cause primary congenital glaucoma. Am J Hum Genet 84: 664-671.

Aponte EP, Diehl N, Mohney BG. 2010. Incidence and clinical characteristics of childhood glaucoma: A populationbased study. Arch Ophthalmol 128: 478-482.

Aroca-Aguilar JD, Martínez-Redondo F, Sánchez-Sánchez F, Coca-Prados M, Escribano J. 2010. Functional role of proteolytic processing of recombinant myocilin in selfaggregation. Invest Ophthalmol Vis Sci 51: 72-78.

Aung T, Rezaie T, Okada K, Viswanathan AC, Child AH, Brice G, Bhattacharya SS, Lehmann OJ, Sarfarazi M, Hitchings RA. 2005. Clinical features and course of patients with glaucoma with the E50K mutation in the optineurin gene. Invest Ophthalmol Vis Sci 46: 2816-2822.

Awadalla MS, Thapa SS, Hewitt AW, Burdon KP, Craig JE. 2013. Association of genetic variants with primary angle closure glaucoma in two different populations. PLoS ONE 8: e67903.

Axenovich T, Zorkoltseva I, Belonogova N, van Koolwijk LM, Borodin P, Kirichenko A, Babenko V, Ramdas WD, Amin N, Despriet DD, et al. 2011. Linkage and association analyses of glaucoma related traits in a large pedigree from a Dutch genetically isolated population. J Med Genet 48: 802-809.

Bejjani BA, Stockton DW, Lewis RA, Tomey KF, Dueker DK, Jabak M, Astle WF, Lupski JR. 2000. Multiple CYP1B1 mutations and incomplete penetrance in an inbred population segregating primary congenital glaucoma suggest frequent de novo events and a dominant modifier locus. Hum Mol Genet 9: 367-374.

Blanco-Marchite C, Sánchez-Sánchez F, López-Garrido MP, Iñigez-de-Onzoño M, López-Martínez F, López-Sánchez E, Alvarez L, Rodríguez-Calvo PP, Méndez-Hernández C, Fernández-Vega L, et al. 2011. WDR36 and P53 gene variants and susceptibility to primary open-angle glaucoma: Analysis of gene-gene interactions. Invest Ophthalmol Vis Sci 52: 8467-8478.

Burdon KP, Macgregor S, Hewitt AW, Sharma S, Chidlow G, Mills RA, Danoy P, Casson R, Viswanathan AC, Liu JZ, et al. 2011. Genome-wide association study identifies susceptibility loci for open angle glaucoma at TMCO1 and CDKN2B-AS1. Nat Genet 43: 574-578.

Chakrabarti S, Ghanekar Y, Kaur K, Kaur I, Mandal AK, Rao KN, Parikh RS, Thomas R, Majumder PP. 2010. A polymorphism in the CYP1B1 promoter is functionally associated with primary congenital glaucoma. $\mathrm{Hum} \mathrm{Mol} \mathrm{Ge-}$ net 19: 4083-4090.
Charlesworth J, Kramer PL, Dyer T, Diego V, Samples JR, Craig JE, Mackey DA, Hewitt AW, Blangero J, Wirtz MK. 2010. The path to open-angle glaucoma gene discovery: Endophenotypic status of intraocular pressure, cup-todisc ratio, and central corneal thickness. Invest Ophthalmol Vis Sci 51: 3509-3514.

Chen H, Lun Y, Ovchinnikov D, Kokubo H, Oberg KC, Pepicelli CV, Can L, Lee B, Johnson RL. 1998. Limb and kidney defects in $L m \times 1 b$ mutant mice suggest an involvement of $L M X 1 B$ in human nail patella syndrome. Nat Genet 19: 51-55.

Choudhary D, Jansson I, Sarfarazi M, Schenkman JB. 2008. Characterization of the biochemical and structural phenotypes of four CYP1B1 mutations observed in individuals with primary congenital glaucoma. Pharmacogenet Genomics 18: 665-676.

Choudhary D, Jansson I, Schenkman JB. 2009. CYP1B1, a developmental gene with a potential role in glaucoma therapy. Xenobiotica 39: 606-615.

Cooke Bailey JN, Sobrin L, Pericak-Vance MA, Haines JL, Hammond CJ, Wiggs JL. 2013. Advances in the genomics of common eye diseases. Hum Mol Genet 22: R59-R65.

Crawford Downs J, Roberts MD, Sigal IA. 2011. Glaucomatous cupping of the lamina cribrosa: A review of the evidence for active progressive remodeling as a mechanism. Exp Eye Res 93: 133-140.

Dreyer SD, Zhou G, Baldini A, Winterpacht A, Zabel B, Cole W, Johnson RL, Lee B. 1998. Mutations in LMX1B cause abnormal skeletal patterning and renal dysplasia in nail patella syndrome. Nat Genet 19: 47-50.

Fan BJ, Ko WC, Wang DY, Canlas O, Ritch R, Lam DS, Pang CP. 2007. Fine mapping of new glaucoma locus GLC1M and exclusion of neuregulin 2 as the causative gene. Mol Vis 13: 779-784.

Fan BJ, Wang DY, Pasquale LR, Haines JL, Wiggs JL. 2011. Genetic variants associated with optic nerve vertical cupto-disc ratio are risk factors for primary open angle glaucoma in a US Caucasian population. Invest Ophthalmol Vis Sci 52: 1788-1792.

Fingert JH, Héon E, Liebmann JM, Yamamoto T, Craig JE, Rait J, Kawase K, Hoh ST, Buys YM, Dickinson J, et al. 1999. Analysis of myocilin mutations in 1703 glaucoma patients from five different populations. Hum Mol Genet 8: 899-905.

Fingert JH, Robin AL, Stone JL, Roos BR, Davis LK, Scheetz TE, Bennett SR, Wassink TH, Kwon YH, Alward WL, et al. 2011. Copy number variations on chromosome 12q14 in patients with normal tension glaucoma. Hum Mol Genet 20: 2482-2494.

Fuchshofer R. 2011. The pathogenic role of transforming growth factor- $\beta 2$ in glaucomatous damage to the optic nerve head. Exp Eye Res 93: 165-169.

Fuchshofer R, Tamm ER. 2012. The role of TGF- $\beta$ in the pathogenesis of primary open-angle glaucoma. Cell Tissue Res 347: 279-290.

Gould DB, John SW. 2002. Anterior segment dysgenesis and the developmental glaucomas are complex traits. Hum Mol Genet 11: 1185-1193.

Gould DB, Mears AJ, Pearce WG, Walter MA. 1997. Autosomal dominant Axenfeld-Rieger anomaly maps to 6p25. Am J Hum Genet 61: 765-768. 
Haji-Seyed-Javadi R, Jelodari-Mamaghani S, Paylakhi SH, Yazdani S, Nilforushan N, Fan JB, Klotzle B, Mahmoudi MJ, Ebrahimian MJ, Chelich N, et al. 2012. LTBP2 mutations cause Weill-Marchesani and Weill-Marchesanilike syndrome and affect disruptions in the extracellular matrix. Hum Mutat 33: 1182-1187.

Hanna IH, Dawling S, Roodi N, Guengerich FP, Parl FF. 2000. Cytochrome P450 1B1 (CYP1B1) pharmacogenetics: Association of polymorphisms with functional differences in estrogen hydroxylation activity. Cancer Res 60: 3440-3444.

Hingorani M, Williamson KA, Moore AT, Van Heyningen V. 2009. Detailed ophthalmologic evaluation of 43 individuals with PAX6 mutations. Invest Ophthalmol Vis Sci 14: 2581-2590.

Jelodari-Mamaghani S, Haji-Seyed-Javadi R, Suri F, Nilforushan N, Yazdani S, Kamyab K, Elahi E. 2013. Contribution of the latent transforming growth factor- $\beta$ binding protein 2 gene to etiology of primary open angle glaucoma and pseudoexfoliation syndrome. Mol Vis 19: $333-$ 347.

Joe MK, Sohn S, Hur W, Moon Y, Choi YR, Kee C. 2003. Accumulation of mutant myocilins in ER leads to ER stress and potential cytotoxicity in human trabecular meshwork cells. Biochem Biophys Res Commun 312 592-600.

Johnson AT, Richards JE, Boehnke M, Stringham HM, Herman SB, Wong DJ, Lichter PR. 1996. Clinical phenotype of juvenile-onset primary open-angle glaucoma linked to chromosome 1q. Ophthalmology 103: 808-814.

Jonas JB, Wang N. 2013. Cerebrospinal fluid pressure and glaucoma. J Ophthalmic Vis Res 8: 257-263.

Kang JH, Wiggs JL, Rosner BA, Hankinson SE, Abdrabou W, Fan BJ, Haines J, Pasquale LR. 2010. Endothelial nitric oxide synthase gene variants and primary open-angle glaucoma: Interactions with sex and postmenopausal hormone use. Invest Ophthalmol Vis Sci 51: 971-979.

Kang JH, Loomis S, Wiggs JL, Stein JD, Pasquale LR. 2012. Demographic and geographic features of exfoliation glaucoma in 2 United States-based prospective cohorts. Ophthalmology 119: 27-35.

Kang JH, Wiggs JL, Pasquale LR. 2013. A nested case control study of plasma ICAM-1, E-selectin and TNF receptor 2 levels, and incident primary open-angle glaucoma. Invest Ophthalmol Vis Sci 54: 1797-1804.

Kim BS, Savinova OV, Reedy MV, Martin J, Lun Y, Gan L, Smith RS, Tomarev SI, John SW, Johnson RL. 2001. Targeted disruption of the myocilin gene (Myoc) suggests that human glaucoma-causing mutations are gain of function. Mol Cell Biol 21: 7707-7713.

Kubota R, Noda S, Wang Y, Minoshima S, Asakawa S, Kudoh J, Mashima Y, Oguchi Y, Shimizu N. 1997. A novel myosin-like protein (myocilin) expressed in the connecting cilium of the photoreceptor: Molecular cloning, tissue expression, and chromosomal mapping. Genomics 41: 360-369.

Lam DS, Leung YF, Chua JK, Baum L, Fan DS, Choy KW, Pang CP. 2000. Truncations in the TIGR gene in individuals with and without primary open-angle glaucoma. Invest Ophthalmol Vis Sci 41: 1386-1391.

Lim SH, Tran-Viet KN, Yanovitch TL, Freedman SF, Klemm T, Call W, Powell C, Ravichandran A, Metlapally R, Nad- ing EB, et al. 2013. CYP1B1, MYOC, and LTBP2 mutations in primary congenital glaucoma patients in the United States. Am J Ophthalmol 155: 508-517.

Liton PB, Liu X, Stamer WD, Challa P, Epstein DL, Gonzalez P. 2005. Specific targeting of gene expression to a subset of human trabecular meshwork cells using the chitinase 3-like 1 promoter. Invest Ophthalmol Vis Sci 46: 183-190.

Loomis SJ, Kang JH, Weinreb RN, Yaspan BL, Cooke Bailey JN, Gaasterland D, Gaasterland T, Lee RK, Lichter PR, Budenz DL, Liu Y, et al. 2014. Association of CAV1/CAV2 genomic variants with primary open-angle glaucoma overall and by gender and pattern of visual field loss. Ophthalmology 121: 508-516.

Lu Y, Vitart V, Burdon KP, Khor CC, Bykhovskaya Y, Mirshahi A, Hewitt AW, Koehn D, Hysi PG, Ramdas WD, et al. 2013. Genome-wide association analyses identify multiple loci associated with central corneal thickness and keratoconus. Nat Genet 45: 155-163.

Macgregor S, Hewitt AW, Hysi PG, Ruddle JB, Medland SE, Henders AK, Gordon SD, Andrew T, McEvoy B, Sanfilippo PG, et al. 2010. Genome-wide association identifies ATOH7 as a major gene determining human optic disc size. Hum Mol Genet 19: 2716-2724.

Manolio TA, Brooks LD, Collins FS. 2008. A HapMap harvest of insights into the genetics of common disease. $J$ Clin Invest 118: 1590-1605.

Mears AJ, Jordan T, Mirzayans F, Dubois S, Kume T, Parlee M, Ritch R, Koop B, Kuo WL, Collins C, et al. 1998. Mutations of the Forkhead/Winged-Helix gene, FKHL7, in patients with Axenfeld-Rieger anomaly. Am J Hum Genet 63: 1316-1328.

Michels-Rautenstrauss KG, Mardin CY, Zenker M, Jordan N, Gusek-Schneider GC, Rautenstrauss BW. 2001. Primary congenital glaucoma: Three case reports on novel mutations and combinations of mutations in the GLC3A (CYP1B1) gene. J Glaucoma 10: 354-357.

Mimiwati Z, Mackey DA, Craig JE, Mackinnon JR, Rait JL, Liebelt JE, Ayala-Lugo R, Vollrath D, Richards JE. 2006. Nail-patella syndrome and its association with glaucoma: A review of eight families. Br J Ophthalmol 90: 15051509.

Minegishi Y, Iejima D, Kobayashi H, Chi ZL, Kawase K, Yamamoto T, Seki T, Yuasa S, Fukuda K, Iwata T. 2013. Enhanced optineurin E50K-TBK1 interaction evokes protein insolubility and initiates familial primary openangle glaucoma. Hum Mol Genet 22: 3559-3567.

Morton S, Hesson L, Peggie M, Cohen P. 2008. Enhanced binding of TBK1 by an optineurin mutant that causes a familial form of primary open angle glaucoma. FEBS Lett 582: 997-1002.

Munaut C, Lambert V, Noël A, Frankenne F, Deprez M, Foidart JM, Rakic JM. 2001. Presence of oestrogen receptor type $\beta$ in human retina. Br J Ophthalmol 85: 877-882.

Narooie-Nejad M, Paylakhi SH, Shojaee S, Fazlali Z, Kanavi MR, Nilforushan N, Yazdani S, Babrzadeh F, Suri F, Ronaghi M, et al. 2009. Loss of function mutations in the gene encoding latent transforming growth factor $\beta$ binding protein 2, LTBP2, cause primary congenital glaucoma. Hum Mol Genet 18: 3969-3977.

Naumann GO, Schlötzer-Schrehardt U, Küchle M. 1998. Pseudoexfoliation syndrome for the comprehensive oph- 
thalmologist: Intraocular and systemic manifestations. Ophthalmology 105: 951-968.

Pang CP, Fan BJ, Canlas O, Wang DY, Dubois S, Tam PO, Lam DS, Raymond V, Ritch R. 2006. A genome-wide scan maps a novel juvenile-onset primary open angle glaucoma locus to chromosome 5q. Mol Vis 12: 85-92.

Pasquale LR, Kang JH. 2009. Lifestyle, nutrition and glaucoma. J Glaucoma 18: 423.

Pasquale LR, Loomis SJ, Weinreb RN, Kang JH, Yaspan BL, Bailey JC, Gaasterland D, Gaasterland T, Lee RK, Scott WK, et al. 2013. Estrogen pathway polymorphisms in relation to primary open angle glaucoma: An analysis accounting for gender from the United States. Mol Vis 19: 1471-1481.

Ramdas WD, van Koolwijk LM, Ikram MK, Jansonius NM, de Jong PT, Bergen AA, Isaacs A, Amin N, Aulchenko YS, Wolfs RC, et al.. 2010. A genome-wide association study of optic disc parameters. PLoS Genet 6: e1000978.

Ramdas WD, van Koolwijk LM, Ikram MK, Jansonius NM, de Jong PT, Bergen AA, Isaacs A, Amin N, Aulchenko YS, Wolfs RC, et al. 2011. Common genetic variants associated with open-angle glaucoma. Hum Mol Genet 20: 2464-2471.

Reis LM, Tyler RC, Volkmann Kloss BA, Schilter KF, Levin AV, Lowry RB, Zwijnenburg PJ, Stroh E, Broeckel U, Murray JC, et al. 2012. PITX2 and FOXC1 spectrum of mutations in ocular syndromes. Eur J Hum Genet 20: $1224-$ 1233.

Rezaie T, Child A, Hitchings R, Brice G, Miller L, CocaPrados M, Héon E, Krupin T, Ritch R, Kreutzer D, et al. 2002. Adult-onset primary open-angle glaucoma caused by mutations in optineurin. Science 295: 1077-1079.

Richards AJ, Yates JR, Williams R, Payne SJ, Pope FM, Scott JD, Snead MP. 1996. A family with Stickler syndrome type 2 has a mutation in the COL11A1 gene resulting in the substitution of glycine 97 by valine in a1(XI) collagen. Hum Mol Genet 5: 1339-1343.

Riise R, Storhaug K, Brøndum-Nielsen K. 2001. Rieger syndrome is associated with PAX6 deletion. Acta Ophthalmol Scand 79: 201-203.

Roh M, Zhang Y, Murakami Y, Thanos A, Lee SC, Vavvas DG, Benowitz LI, Miller JW. 2012. Etanercept, a widely used inhibitor of tumor necrosis factor- $\alpha$ (TNF- $\alpha$ ), prevents retinal ganglion cell loss in a rat model of glaucoma. PLOS ONE 7: e40065.

Russo R, Cavaliere F, Watanabe C, Nucci C, Bagetta G, Corasaniti MT, Sakurada S, Morrone LA. 2008. 17ß-Estradiol prevents retinal ganglion cell loss induced by acute rise of intraocular pressure in rat. Prog Brain Res 173: 583-590.

Sarfarazi M, Stoilov I. 2000. Molecular genetics of primary congenital glaucoma. Eye 14: 422-428.

Sarfarazi M, Akarsu NA, Hossain A, Turacli EM, Aktan GS, Barsoum-Homsy M, Chevrette L, Sayli SB. 1995. Assignment of a locus (GLC3A) for primary congenital glauco$\mathrm{ma}$ (Buphthalmos) to 2p21 and evidence for genetic heterogeneity. Genomics 30: 2171-2177.

Schlötzer-Schrehardt U. 2009. Molecular pathology of pseudoexfoliation syndrome/glaucoma-New insights from LOXL1 gene associations. Exp Eye Res 88: 776-785.

Schlötzer-Schrehardt U, Naumann GO. 1995. Trabecular meshwork in pseudoexfoliation syndrome with and without open-angle glaucoma. A morphometric, ultrastructural study. Invest Ophthalmol Vis Sci 36: 17501764.

Sethi A, Mao W, Wordinger RJ, Clark AF. 2011. Transforming growth factor $-\beta$ induces extracellular matrix protein cross-linking lysyl oxidase (LOX) genes in human trabecular meshwork cells. Invest Ophthalmol Vis Sci 52: 5240 5250 .

Sharafieh R, Child AH, Khaw PT, Fleck B, Sarfarazi M. 2013. $L T B P 2$ gene analysis in the $G L C 3 C$-linked family and 94 CYP1B1-negative cases with primary congenital glaucoma. Ophthalmic Genet 34: 14-20.

Sheffield VC, Stone EM, Alward WL, Drack AV, Johnson AT, Streb LM, Nichols BE. 1993. Genetic linkage of familial open angle glaucoma to chromosome 1q21-q31. Nat Genet 4: 47-50.

Sowers MR, Wilson AL, Kardia SR, Chu J, McConnell DS. 2006. CYP1A1 and CYP1B1 polymorphisms and their association with estradiol and estrogen metabolites in women who are premenopausal and perimenopausal. Am J Med 119: S44-S51.

Stein JD, Pasquale LR, Talwar N, Kim DS, Reed DM, Nan B, Kang JH, Wiggs JL, Richards JE. 2011. Geographic and climatic factors associated with exfoliation syndrome. Arch Ophthalmol 129: 1053-1060.

Stoilov I, Akarsu AN, Sarfarazi M. 1997. Identification of three different truncating mutations in cytochrome P4501B1 (CYP1B1) as the principal cause of primary congenital glaucoma (Buphthalmos) in families linked to the GLC3A locus on chromosome 2p21. Hum Mol Genet 6: 641-647.

Stoilov IR, Sarfarazi M. 2002. The third genetic locus (GLC3C) for primary congenital glaucoma (PCG) maps to chromosome 14q24.3. Invest Ophthalmol Vis Sci 43: E3015.

Stone EM, Fingert JH, Alward WL, Nguyen TD, Polansky JR, Sunden SL, Nishimura D, Clark AF, Nystuen A, Nichols BE, et al. 1997. Identification of a gene that causes primary open angle glaucoma. Science 275: 668-670.

Sud N, Wiseman DA, Black SM. 2010. Caveolin 1 is required for the activation of endothelial nitric oxide synthase in response to 17ß-estradiol. Mol Endocrinol 24: 16371649.

Swiderski RE, Reiter RS, Nishimura DY, Alward WL, Kalenak JW, Searby CS, Stone EM, Sheffield VC, Lin JJ. 1999. Expression of the $M f 1$ gene in developing mouse hearts: Implication in the development of human congenital heart defects. Dev Dyn 216: 16-27.

Thorleifsson G, Magnusson KP, Sulem P, Walters GB, Gudbjartsson DF, Stefansson H, Jonsson T, Jonasdottir A, Jonasdottir A, Stefansdottir G, et al. 2007. Common sequence variants in the LOXL1 gene confer susceptibility to exfoliation glaucoma. Science 317: 1397-1400.

Thorleifsson G, Walters GB, Hewitt AW, Masson G, Helgason A, DeWan A, Sigurdsson A, Jonasdottir A, Gudjonsson SA, Magnusson KP, et al. 2010. Common variants near CAV1 and CAV2 are associated with primary openangle glaucoma. Nat Genet 42: 906-909.

Toh T, Liew SH, MacKinnon JR, Hewitt AW, Poulsen JL, Spector TD, Gilbert CE, Craig JE, Hammond CJ, Mackey DA. 2005. Central corneal thickness is highly heritable: 
The twin eye studies. Invest Ophthalmol Vis Sci 46: 3718 3722.

Tokizane T, Shiina H, Igawa M, Enokida $\mathrm{H}$, Urakami S, Kawakami T, Ogishima T, Okino ST, Li LC, Tanaka Y, et al. 2005. Cytochrome P450 1B1 is overexpressed and regulated by hypomethylation in prostate cancer. Clin Cancer Res 11: 5793-5801.

Tsuchiya Y, Nakajima M, Yokoi T. 2005. Cytochrome P450mediated metabolism of estrogens and its regulation in human. Cancer Lett 227: 115-124.

Ueda J, Wentz-Hunter K, Yue BY. 2002. Distribution of myocilin and extracellular matrix components in the juxtacanalicular tissue of human eyes. Invest Ophthalmol Vis Sci 43: $1068-1076$.

van Koolwijk LM, Ramdas WD, Ikram MK, Jansonius NM, Pasutto F, Hysi PG, Macgregor S, Janssen SF, Hewitt AW, Viswanathan AC, et al. 2012. Common genetic determinants of intraocular pressure and primary open-angle glaucoma. PLoS Genet 8: e1002611.

Vithana EN, Aung T, Khor CC, Cornes BK, Tay WT, Sim X, Lavanya R, Wu R, Zheng Y, Hibberd ML, et al. 2011. Collagen-related genes influence the glaucoma risk factor, central corneal thickness. Hum Mol Genet 20: 649658.

Vithana EN, Khor CC, Qiao C, Nongpiur ME, George R, Chen LJ, Do T, Abu-Amero K, Huang CK, Low S, et al. 2012. Genome-wide association analyses identify three new susceptibility loci for primary angle closure glaucoma. Nat Genet 44: 1142-1146.

Volkmann BA, Zinkevich NS, Mustonen A, Schilter KF, Bosenko DV, Reis LM, Broeckel U, Link BA, Semina EV. 2011. Potential novel mechanism for Axenfeld-Rieger syndrome: Deletion of a distant region containing regulatory elements of PITX2. Invest Ophthalmol Vis Sci 52: $1450-1459$.

Wang DY, Fan BJ, Canlas O, Tam PO, Ritch R, Lam DS, Fan DS, Pang CP. 2004. Absence of myocilin and optineurin mutations in a large Philippine family with juvenile onset primary open angle glaucoma. Mol Vis 10: 851-856.

Wang DY, Fan BJ, Chua JK, Tam PO, Leung CK, Lam DS, Pang CP. 2006. A genome-wide scan maps a novel juvenile-onset primary open-angle glaucoma locus to $15 \mathrm{q}$ Invest Ophthalmol Vis Sci 47: 5315-5321.

Wiggs JL, Vollrath D. 2001. Molecular and clinical evaluation of a patient hemizygous for TIGR/MYOC. Arch Ophthalmol 119: 1674-1678.

Wiggs JL, Del Bono EA, Schuman JS, Hutchinson BT, Walton DS. 1995. Clinical features of five pedigrees genetically linked to the juvenile glaucoma locus on chromosome 1q21-q31. Ophthalmology 102: 1782-1789.

Wiggs JL, Allingham RR, Vollrath D, Jones KH, De La Paz M, Kern J, Patterson K, Babb VL, Del Bono EA, Broomer BW, et al. 1998. Prevalence of mutations in TIGR/Myocilin in patients with adult and juvenile primary open-angle glaucoma. Am J Hum Genet 63: 1549-1552.

Wiggs JL, Lynch S, Ynagi G, Maselli M, Auguste J, Del Bono EA, Olson LM, Haines JL. 2004. A genomewide scan identifies novel early-onset primary open-angle glaucoma loci on 9q22 and 20p12. Am J Hum Genet 74: 13141320.
Wiggs JL, Kang JH, Yaspan BL, Mirel DB, Laurie C, Crenshaw A, Brodeur W, Gogarten S, Olson LM, Abdrabou W, et al. 2011. Common variants near CAV1 and CAV2 are associated with primary open-angle glaucoma in Caucasians from the USA. Hum Mol Genet 20: 4707-4713.

Wiggs JL, Kang JH, Yaspan BL, Mirel DB, Laurie C, Crenshaw A, Brodeur W, Gogarten S, Olson LM, Abdrabou W, et al. 2012. Common variants at 9p21 and $8 \mathrm{q} 22$ are associated with increased susceptibility to optic nerve degeneration in glaucoma. PLoS Genet 8: e1002654.

Wiggs JL, Hauser MA, Abdrabou W, Allingham RR, Budenz DL, Delbono E, Friedman DS, Kang JH, Gaasterland D, Gaasterland T, et al. 2013a. The NEIGHBOR Consortium primary open-angle glaucoma genome-wide association study: Rationale, study design, and clinical variables. $J$ Glaucoma 22: 517-525.

Wiggs JL, Howell GR, Linkroum K, Abdrabou W, Hodges E, Braine CE, Pasquale LR, Hannon GJ, Haines JL, John SW. 2013b. Variations in COL15A1 and COL18A1 influence age of onset of primary open angle glaucoma. Clin Genet 84: $167-174$.

Winnier GE, Kume T, Deng K, Rogers R, Bundy J, Raines C, Walter MA, Hogan BL, Conway SJ. 1999. Roles for the winged helix transcription factors MF1 and MFH1 in cardiovascular development revealed by nonallelic noncomplementation of null alleles. Dev Biol 213: 418-431.

Yam GH, Gaplovska-Kysela K, Zuber C, Roth J. 2007. Sodium 4-phenylbutyrate acts as a chemical chaperone on misfolded myocilin to rescue cells from endoplasmic reticulum stress and apoptosis. Invest Ophthalmol Vis Sci 48: $1683-1690$.

Ying H, Yue BY. 2012. Cellular and molecular biology of optineurin. Int Rev Cell Mol Biol 294: 223-258.

Zhou X, Li F, Ge J, Sarkisian SR, Tomita H, Zaharia A, Chodosh J, Cao W. 2007. Retinal ganglion cell protection by $17-\beta$-estradiol in a mouse model of inherited glaucoma. Dev Neurobiol 67: 603-616.

Zhou YY, Zhao Y, Mirza MK, Huang JH, Potula HHSK, Vogel SM, Brovkovych V, Yuan JXJ, Wharton J, Malik AB. 2009. Persistent eNOS activation secondary to caveolin-1 deficiency induces pulmonary hypertension in mice and humans through PKG nitration. J Clin Invest 119: 2009-2018.

Zode GS, Clark AF, Wordinger RJ. 2009. Bone morphogenetic protein 4 inhibits TGF- $\beta 2$ stimulation of extracellular matrix proteins in optic nerve head cells: Role of gremlin in ECM modulation. Glia 57: 755-766.

Zode GS, Kuehn MH, Nishimura DY, Searby CC, Mohan K, Grozdanic SD, Bugge K, Anderson MG, Clark AF, Stone EM, et al. 2011. Reduction of ER stress via a chemical chaperone prevents disease phenotypes in a mouse model of primary open angle glaucoma. J Clin Invest 121: 3542-3553.

Zode GS, Bugge KE, Mohan K, Grozdanic SD, Peters JC, Koehn DR, Anderson MG, Kardon RH, Stone EM, Sheffield VC. 2012. Topical ocular sodium 4-phenylbutyrate rescues glaucoma in a myocilin mouse model of primary open-angle glaucoma. Invest Ophthalmol Vis Sci 53: 1557-1565. 


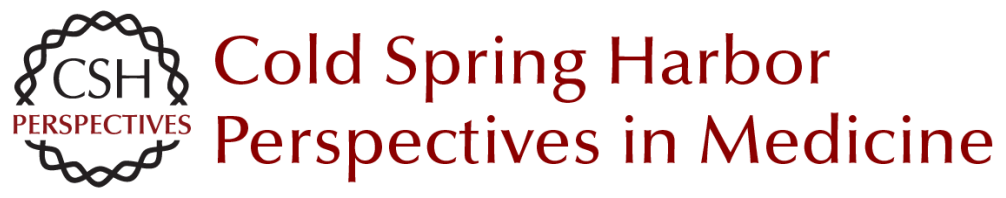

\section{Common and Rare Genetic Risk Factors for Glaucoma}

Ryan Wang and Janey L. Wiggs

Cold Spring Harb Perspect Med 2014; doi: 10.1101/cshperspect.a017244 originally published online September 18, 2014

Subject Collection Retinal Disorders: Genetic Approaches to Diagnosis and Treatment

Trial by "Firsts": Clinical Trial Design and Regulatory Considerations in the Development and Approval of the First AAV Gene Therapy Product in the United States

Kathleen Z. Reape and Katherine A. High

Immunology of Retinitis Pigmentosa and Gene Therapy-Associated Uveitis

Paul Yang, Debarshi Mustafi and Kathryn L. Pepple

Developing New Vectors for Retinal Gene Therapy

Emilia A. Zin, Bilge E. Ozturk, Deniz Dalkara, et al.

Beyond the NEI-VFQ: Recent Experience in the Development and Utilization of Patient-Reported

Outcomes for Inherited Retinal Diseases

Todd Durham, Judit Banhazi, Francesco Patalano, et al.

Electronic Retinal Prostheses

Daniel Palanker

Alternative RNA Splicing in the Retina: Insights and Perspectives

Casey J. Keuthan, Sadik Karma and Donald J. Zack

X-Linked Retinoschisis

Cristy A. Ku, Lisa W. Wei and Paul A. Sieving

A Systematic Review of Optogenetic Vision Restoration: History, Challenges, and New Inventions from Bench to Bedside

Antonia Stefanov and John G. Flannery
Lessons Learned from the Development of the First FDA-Approved Gene Therapy Drug, Voretigene Neparvovec-rzyl Jean Bennett and Albert M. Maguire

Therapeutic Gene Editing in Inherited Retinal Disorders Jinjie Ling, Laura A. Jenny, Ashley Zhou, et al.

Cell-Based Therapies: Strategies for Regeneration Marina Pavlou and Thomas A. Reh

The Importance of Natural History Studies in Inherited Retinal Diseases Allison Ayala, Janet Cheetham, Todd Durham, et al.

Photoreceptor Cell Replacement Using Pluripotent Stem Cells: Current Knowledge and Remaining Questions

Christelle Monville, Olivier Goureau and Karim Ben M'Barek

iPSC-RPE in Retinal Degeneration: Recent

Advancements and Future Perspectives

Tadao Maeda and Masayo Takahashi

Retinal Degeneration Animal Models in Bardet-

Biedl Syndrome and Related Ciliopathies Clarisse Delvallée and Hélène Dollfus

Mobility Testing and Other Performance-Based Assessments of Functional Vision in Patients with Inherited Retinal Disease

Daniel Chung, Colas Authié and Laure Blouin

For additional articles in this collection, see http://perspectivesinmedicine.cshlp.org/cgi/collection/ 
For additional articles in this collection, see http://perspectivesinmedicine.cshlp.org/cgi/collection/ 